33. アラスカにおける大気污染物質の測定之流䟢線による解析

\title{
BACKWARD TRAJECTORY ANALYSIS OF AIR POLUTANTS MEASURED AT BARROW, ALASKA
}

○下羽利明 $*$ 村尾直人* $・$ 太田幸雄 ${ }^{*} \cdot$ 山形定 $^{*}$ *北海道大学大学院工学研究科

Toshiaki SHITABA*, Naoto MURAO*, Sachio OHTA*, Sadamu YAMAGATA* ${ }^{*}$ Graduate School of Engineering, Hokkaido University

\begin{abstract}
ABSTRUCT ; VOCs and aerosols sampling was conducted at Barrow, Alaska, USA from July, 1999 to July, 2001, to obtain their seasonal variation.Heavy metals, EC and sulfate concentration showed minimum in summer and autumn, and maximum in winter and spring, which is the character of Arctic Haze.Some VOCs(Xylene etc.) also showed the same seasonal variation, which suggest that VOCs are the component of Arctic Haze.

To verify a difference in transport pathways between in winter and in summer, 5day backward trajectories were constructed. In winter and spring, some trajectories indicated long-range transport from emission sources in Eurasia. It was thus considered that long-range transport from emission sources in Eurasia was one of the causes of Arctic Haze at Barrow.
\end{abstract}

Key Words; Arctic Haze, aerosols, VOCs, backward trajectory analysis

\section{1 はじめに}

北極圈は人間活動による污染発生源が非常に少ないため, 清浄な地域のであると考えられてきた。しかし, 1970 年以降, 冬〜春季にかけて, 北半球中緯度人為污染源からの輸送によるアークテイックヘイズと呼ばれる污染気塊 が確認されるようになった。このへイズは主に, 重金属 (バナジウム, 鉛等), 硫酸成分, 黒色順炭素等のエアロゾル 成分で構成されるが, これらの污染物質は, 太陽放射を散乱, 吸収することによる, 地球温暖化に寄与することや, 北極海や北極海沿岸の氷河の表面, ツンドラ土袞の表面に沈着, 蓄積され, 動植物など生態系に影響を及ぼすこ とが懸念されている。

ヘイズの主な成分は, 先に述べたように, エアロゾル成分であるが, 揮発性有機化合物 (VOCs)の中にも, 人間 活動によって排出される成分が存在する。しかし，アラスカにおけるVOCs の測定例は少ない。そこで本研究では, 北極海に面するアラスカ州の町, バロー $\left(71.32^{\circ} \mathrm{N}, 156.60^{\circ} \mathrm{W}\right)$ において, 大気中の重金属, 黒色純炭素などの工 アロゾル成分, ならびにキシレン, エチルベンゼンなどの VOCs 成分の通年の測定を行い, アークティックヘイズと の関係を調べることを目的とした。また, バローからの後退流跡線解析により,アークテイックヘイズ期と他の時期と の空気隗の輸送状態の比較を行い, また, 発生源と考えられる地域からの寄与を検討した。

\section{2 大気污染物質の測定}

\subsection{VOC 成分の測定}

\section{(1) 測定, 分析方法}

測定, 分析は, 吸着捕集加熱脱離法を用いて行った。本法では, ガラス管に炭素系の吸着剤が三層に渡って 
充填された, マルチベッド型捕集管 (Carbotrap317;SUPELCO)にポンプで空気を吸引することにより, 試料を採取 した。捕集された試料を試料導入装置TCT-4020 (CHROMPACK) にセットし加熱脱離, 極低温部で二次濃縮を 行い, その後極低温部を急激に加熱し, 試料を GC に注入し成分の分離を行い, 質量分析装置で検出を行う。

\section{(2) 期間}

2000 年 3 月〜2001 年 12 月までの期間, バローにおいて, 月 1 回程度のサンプリングを実施した。また, 2001 年 7 月末に, 実際に現地での野外サンプリングも実施した。

\section{(3) サンプリング系}

捕集間入り口に, 除湿管を接続し, 出口側に流量計, ポンプを接続する(図 1)。

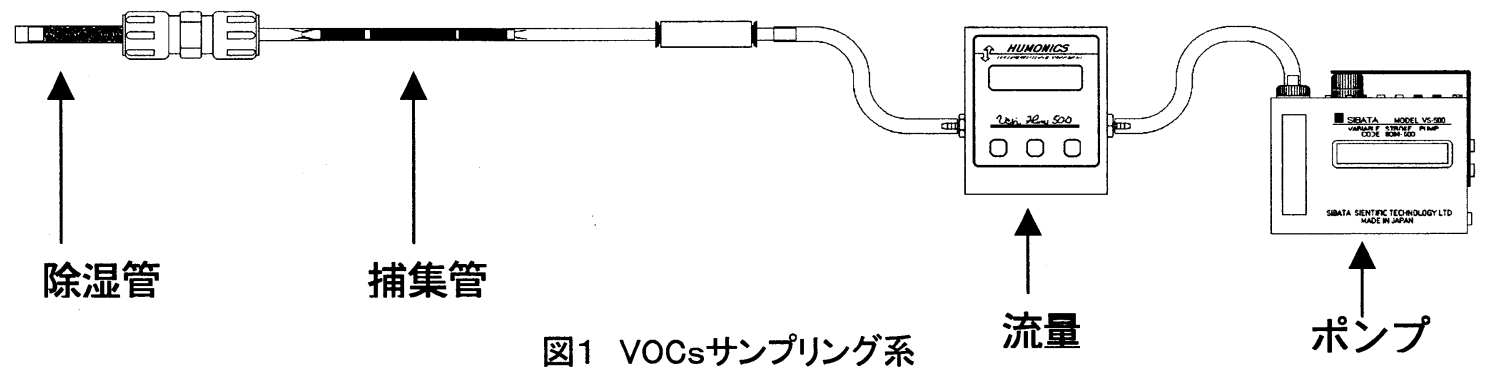

この系をサンプリングを依頼している NOAA/CMDL の施設内に設置し, サンプリングを行った。サンプリング流 量は $100 \mathrm{~mL} / \mathrm{min}$, 採気時間は 2 時間である。この施設の周りには, ツンドラ平原が広がっており, ローカルな污染 を受けにくい地域に位置する。また, 地上から約 $10 \mathrm{~m}$ に位置する大気の取り入れ口から大気を取り入れている。

\section{(4) 結果}

分析の結果のうち,いくつか特徵的であったVOCsの濃度の季節変動を図 4 に示す。Ethylbenzen, p,m-Xylene, Styrene，1,4-Dichlorobenzen などの物質は, 冬期から春期にかけて濃度が上昇する傾向が見られ た。これらの成分は, 主に自動車排ガスや燃焼などの人為起源によるものである。この傾向は, 次章に示す重金 属成分や黒色純炭素, 硫酸成分などの人為起源のエアロゾル成分にも見られる濃度の変動と一致し, また, アー クティックヘイズに特徵的な傾向でもある。このことから, アークティックヘイズ中のVOCsの存在が示唆された。ま た, Chloroform のように, 年間を通してほぼ一定の濃度で推移するものや, これらの傾向とは関係なく増減する物 質もあった。

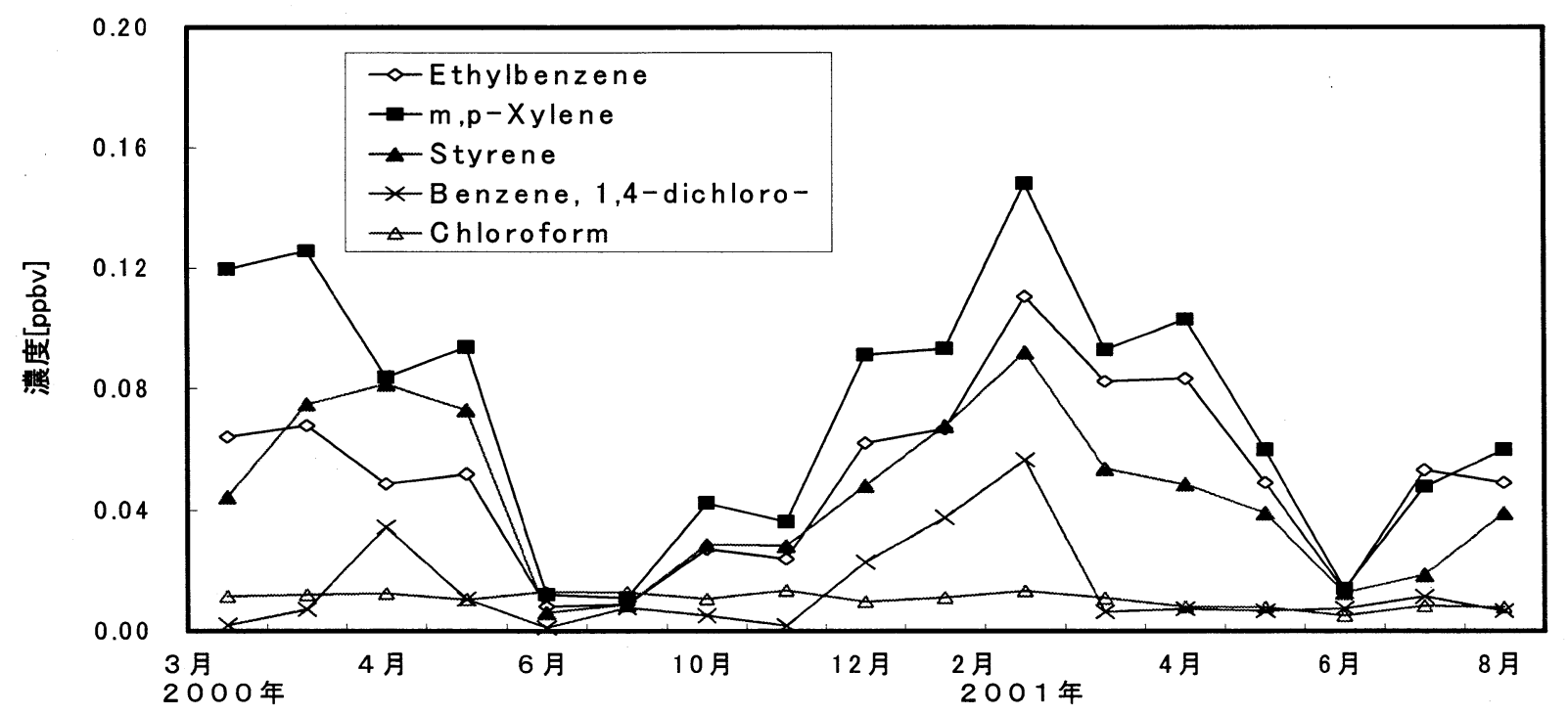

図2 バローにおける VOCs 濃度の季節変化 


\section{2 エアロゾル成分の測定}

\section{(1) 測定, 分析方法}

対象とする成分は, 炭素成分, 水溶性成分, 重金属成分の 3 つである。炭素成分の捕集には石英繊維つィ ルターを, また水溶性成分, 重金属成分の捕集にはテフロンフィルターを用いた。サンプルの分析は, 炭素成 分はカーボンアナライザーで, 水溶性成分はイオンクロマトグラフィーで, 重金属成分は ICP-MASS で, それ ぞれ分析を行った。

\section{(2) 期間}

測定期間は 1999 年 7 月〜2001 年 7 月までの約 2 年間でサンプリング地点は, 2.1 と同じ, アラスカ州のバロ 一にて行った。

\section{(3) サンプリング系}

フィルターホルダーに固定された石英繊維フィルターとテフロンフィルターを, 2 系を並列に繋ぎ, 同時にサ ンプリングを行った。採気流量は $20 \mathrm{~mL} / \mathrm{min}$, 採気時間は 2 週間で, 月に 2 回, 行った。

\section{(4) 結果}

図 3 は, 測定したエアロゾル各成分の濃度を積算で示したものである。黒色純炭素, 硫酸などの成分で, 冬期 〜春期にかけて, 濃度の上昇がみられる。れは, アークテイックヘイズの特徴と一致する。また, バローは北極 海に面しているため, 海塩起源の粒子の割合は高くなっている。図 4 は, 測定したエアロゾル中の重金属成分の 濃度の季節変動を表したものである。各成分で, 冬期から春期にかけて, 濃度の上昇がみられる。黒色純炭素粒 子やバナジウム, ニッケル, 砒素および鉛などの物質は, ボイラー排煙や石炭燃焼による排煙および, 自動車排 ガスなどに高濃度に含まれる成分であり，人間活動の結果として排出された成分である。重金属成分では, 特に 鉛, 垔鉛で, 顕著な濃度変動を示した。

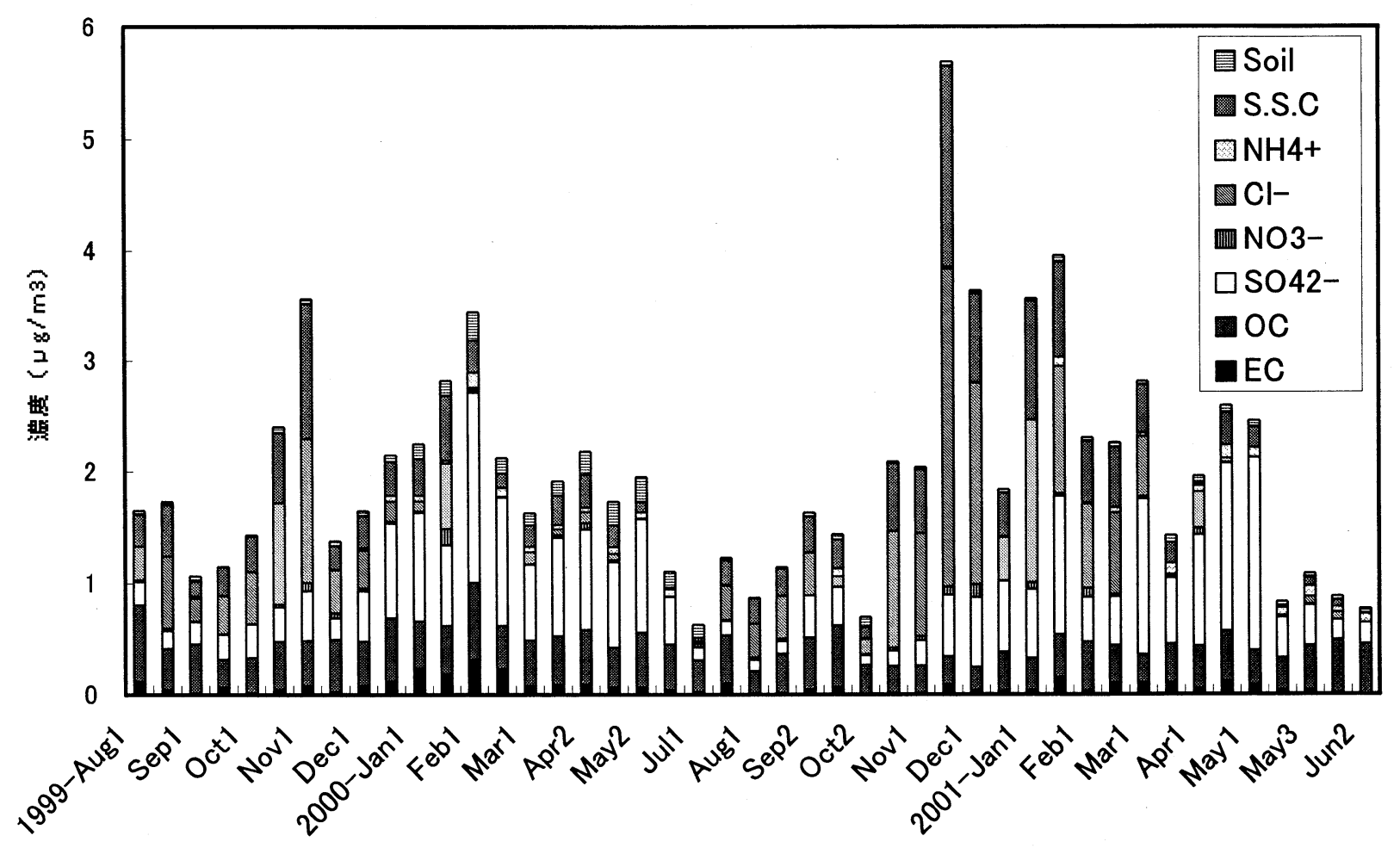

図3 バローにおけるエアロゾル濃度の季節変化 


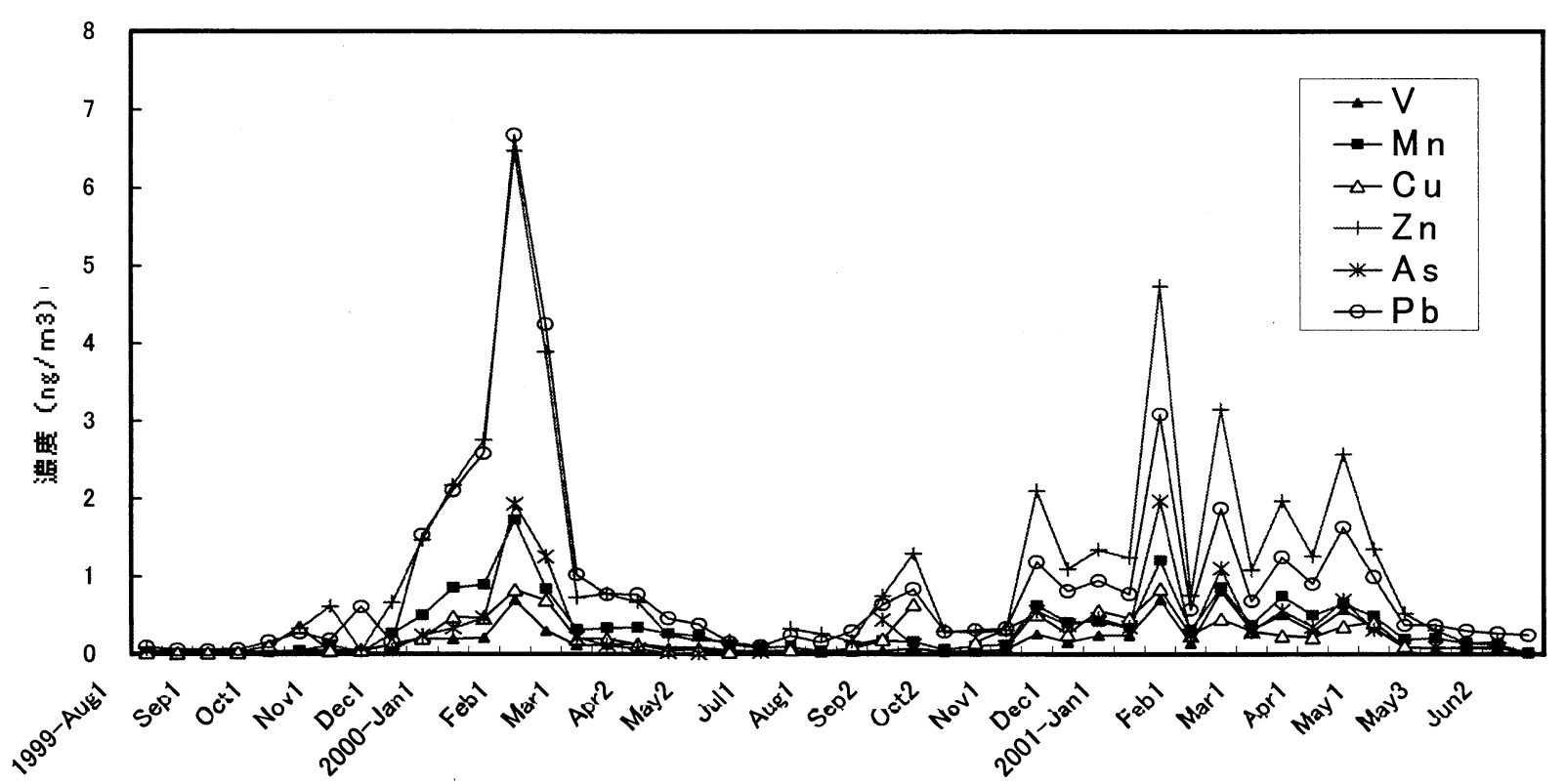

図4 バローにおける重金属成分の季節変化

\section{3 後退流跡線による解析}

\section{1 流跡線解析}

2.1 や 2.2 で得られた, バローにおける大気中の重金属やVOCs などのエアロゾル成分濃度の, 季節変動をも とに, バローに到達する空気隗の移動状態や, 発生源地域からの污染物質の寄与を得ることなどを目的に, バロ 一からの5日間の後退流跡線解析を行った。夏季における流跡線解析の一例を図5に, 冬期における一例を図 6 に示す。冬期では, 夏季に比べ, 遠方からの流跡線が多く, ロシアの東欧地域工業地帯方面からの流入も見られ る。また, 鈶直方向の気塊の移動も, 夏季に比べ小さい。一方, 夏季においては, 流跡線の遠方からの流入はあ まり見られず, 発生源と考えられるユーラシア地域からの流入も夏季に比べるとほとんどない。
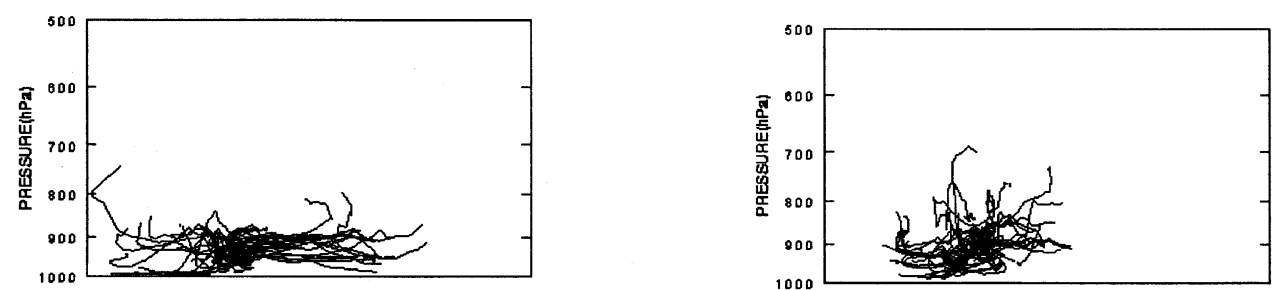

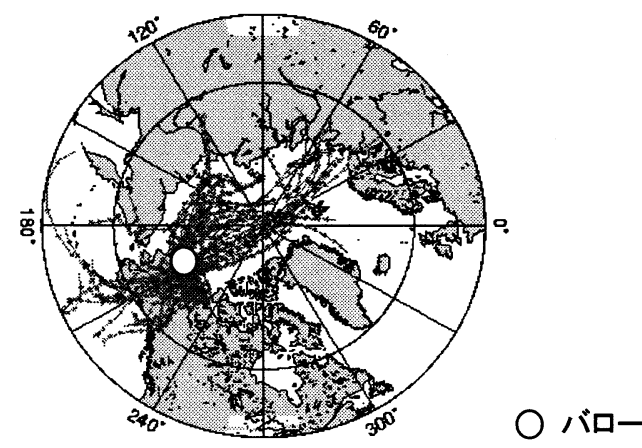

図5 2000 年 1 月の流跡線

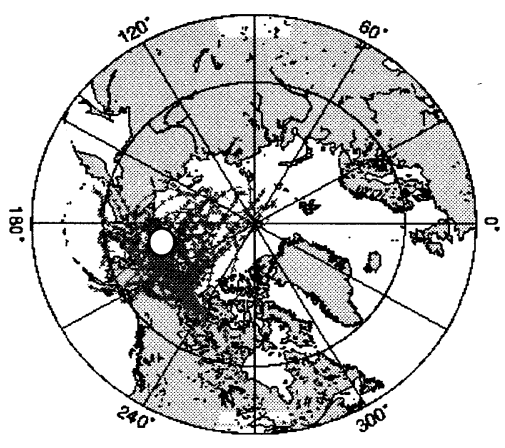

図6 2000 年 7 月の流跡線 


\section{2 発生源地域の寄与}

図 7,8は, 流跡線の結果をもとに, 北緯 $45^{\circ}$ 以北の全域を 13 のブロックに分け, 5 日前に, 気塊がどの地域 からどのくらいの頻度でやってきたかを示したものである。ブロックは, 北緯 $70^{\circ}$ 以北を $1 つ$, 北緯 $45^{\circ} \sim 70^{\circ}$ の 区間は, 経度 $30^{\circ}$ ごとに 12 分割し, 計 13 分割とした。図中のバーが高いほど, 5 日前に気塊がそのブロックを通 った頻度が多いことを表している。図には, 2000年の 1 月〜 月 (冬〜春季)と 5 月〜8月 (春〜夏季)のそれぞれ 4 ケ月間を積算し, 示した。

どちらの季節においても, 過半数の流跡線は, 北緯 $70^{\circ}$ 以北の北極圈からの流入であり, 北極圈内の空気隗 は, 5 日前にはそのほとんどが北極圏内にあるといえる。また, 冬〜春季にかけては, ユーラシア大陸の污染地 域からの流入があるが, それほど高い割合ではない。これらのことから, 冬季, 長距離輸送されてくる污染物質は, 一度北極圈内に入ると, その中を循環し, 圈外に輸送されにくく, 蓄積されることによって, 濃度が上昇していくと 考えられる。さらに, 冬季は, 地表近くの気塊は鉛直方向に混合されることなく, そのまま地表付近を移動する。 加えて, 冬季の北極圏は降水も少ないため, 大気中からの污染物質の除去が行われない。これらの要素が, 大 規模な人為発生源からの重金属や VOCs 成分の濃度が, バローや北極圈で, 冬季に高くなる原因であると考え られる。

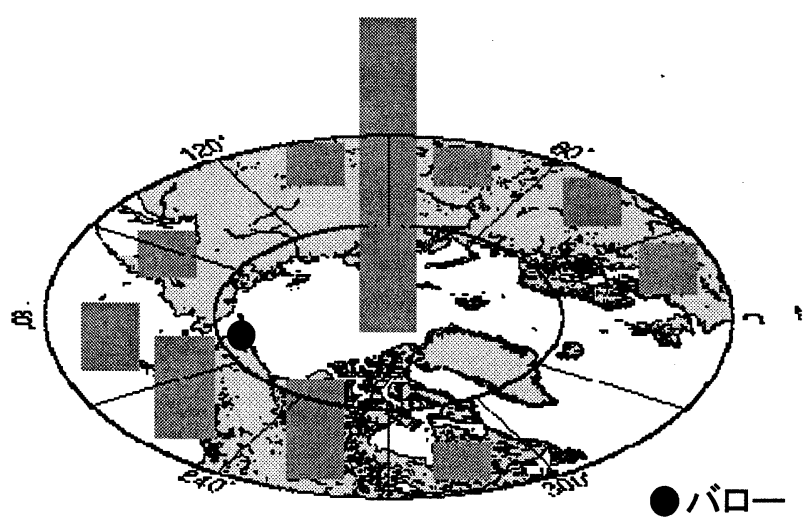

図7 2000 年 1 月 4 月

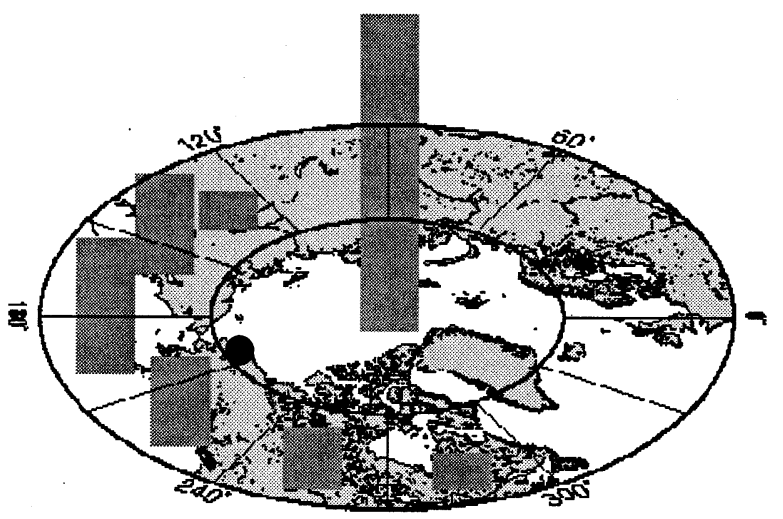

図8 2000 年 5 月 8 月

図7，8:バローからの5日間の流跡線の終点となった地点を，終点となった回数の割合で表している。 バーが高いほど, 流跡線の終点であった割合が高く。その地域からの気塊の流入があること を示している。

\section{4 まとめ}

アラスカ北極圏におけるエアロゾル成分, VOCs 成分の濃度を測定した。キシレン類, スチレン類などいくつか の VOC 成分で, エアロゾル成分の濃度が増加する冬〜春季にかけて, 同様に濃度の増加があった。このことより, 中緯度人為污染源から輸送されてくる污染空気隗の中には, VOCs成分も含まれていることが示唆され, アークテ イックヘイズとの関連も見られた。

流跡線解析の結果より, 夏季に比べて, 冬〜春季におけるユーラシア地域などの污染発生源地域からの北極 圈への気塊の輸送量が多いことが示唆された。また，5日間でバローに到達する空気隗の約 5 割以上は北極圈内 からやってきており,アークテイックヘイズ期における, 污染地域からの流入は, 比較的小さいものであった。しか 
しながら, それと同時に, 污染空気隗が一度北極圏内に流入すると, 北極圈外には出て行きにくく, その中を漂う ことになり, 濃度の上昇を招くことになる。これらのことから, ユーラシア地域の污染発生源地域が, バローにおけ

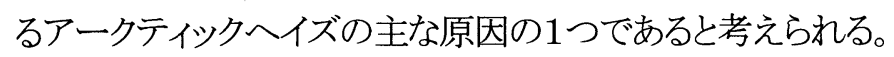

\section{参考文献}

1) A.V.Polissar , P.K.Hopke , P.Paatero , Y.J.Kaufmann , D.K.Hall , B.A.Bodhaine , E.G.Dutton , J.M.Harris : The aerosol at Barrow, Alaska:long-term trends and source locations , Atmospheric Environment, Vol.33, pp2441-2458, 1999

2)NOAA air Resources Laboratory : http://www.arl.noaa.gov/ready/hysplit4.html 